\title{
Studi Simulasi Sistem Pada Perusahaan Jasa Pengiriman Barang dan Ekspedisi
}

\author{
Andira ${ }^{1}$, Johan K. Runtuk ${ }^{2}$, Anastasia L. Maukar ${ }^{3}$ \\ 1,2,3) Fakultas Teknik, Jurusan Teknik Industri, Universitas Presiden \\ Jababeka Educational Park, Jl, Ki Hajar Dewantara, Bekasi \\ E-mail: andira@president.ac.id, johan.runtuk@president.ac.id, almaukar@president.ac.id
}

\begin{abstract}
Currently, the competition of delivery service providers is increasing. Companies must strive to improve customer service and satisfaction to survive in this competition. One of the service improvements relates to the queuing system. This research was conducted at the counter of a logistics company, which provides delivery and expedition services, located in Cikarang, Bekasi. There was often a buildup of queues at counters and accumulated goods to be packaged. As a result, officers have very high utilization, because they should serve the customers; meanwhile, they also have to do packing works. This study uses a simulation approach to analyse and improve the performance of the current queuing system. Simulations are carried out using Promodel in the delivery handling system, namely starting when the customer enters the store, handling customer needs (including in the case of packing the goods until the service is complete and the customer leaves the store. There are two suggestions for improvement; short-term and medium-term improvement proposals for the short-term focus on customer service (excluding packaging), namely by providing registration forms and also preparing a refund that can shorten the service process. Meanwhile, the long-term improvement is to strengthen the service system with an additional information system, standardization of processes and costs, as well as extra officers who specialize in packing. The simulation results show that short and mediumterm improvement can reduce waiting time and utilization, and increase the number of goods packed.
\end{abstract}

Keywords: Customer Satisfaction, Queueing System, Simulation, Utilization, Waiting Time

\begin{abstract}
Abstrak
Perusahaan harus terus untuk meningkatkan layanan dan kepuasan pelanggan agar dapat bertahan dalam persaingan dalam layanan pengiriman barang. Salah satu peningkatan layanan yang harus ditingkatkan adalah sistem antrean. Penelitian ini dilakukan di suatu counter dari satu perusahaan logistik, yang menyediakan jasa pengiriman barang dan ekspedisi yang berlokasi di Cikarang, Bekasi dan berskala nasional. Saat ini, di counter sering terjadi penumpukan antrean. Selain disebabkan oleh banyak pengguna jasa di counter ini, penumpukan terjadi karena petugas juga mengerjakan pengemasan item yang akan dikirim. Akibatnya, petugas memiliki utilitas yang sangat tinggi karena selain melayani pelanggan, juga harus mengemas barang yang akan dikirim. Hal tersebut menyebabkan pelanggan yang mengantre merasa tidak puas terhadap pelayanan. Penelitian ini menggunakan pendekatan simulasi untuk menganalisis dan meningkatkan kinerja sistem antrean saat ini. Simulasi dilakukan dengan menggunakan bantuan software Promodel, dan dilakukan pada sistem penanganan pengiriman barang, yaitu mulai saat pelanggan masuk ke dalam toko, penanganan kebutuhan pelanggan (termasuk dalam hal pengepakan barang, sampai dengan layanan selesai dan pelanggan meninggalkan toko. Terdapat dua usulan perbaikan, yaitu jangka pendek dan jangka menengah. Usulan perbaikan jangka pendek difokuskan pada pelayanan terhadap pelanggan (tidak termasuk pengepakan), yaitu dengan menyediakan form pendaftaran dan juga menyiapkan uang pengembalian yang dapat mempersingkat proses layanan. Sedangkan usulan perbaikan jangka panjang adalah dengan memperkuat sistem layanan dengan adanya tambahan sistem informasi, standardisasi proses dan biaya, serta penambahan petugas yang khusus menangani pengepakan. Berdasarkan hasil simulasi, diperoleh bahwa usulan jangka pendek dan menengah dapat mengurangi waktu tunggu pelanggan dan utilitas, serta meningkatkan jumlah barang yang dikemas.
\end{abstract}


Kata kunci: Kepuasan Pelanggan Counter, Simulasi, Sistem Antrean, Utilitas, Waktu Tunggu

\section{Pendahuluan}

Pengiriman barang adalah salah satu kegiatan utama dalam perusahaan yang bergerak dalam jasa/layanan logistik. Layanan logistik berusaha mengoordinasikan interaksi antara pelanggan dan organisasi dengan tujuan untuk mengurangi lead time antara penjadwalan, meningkatkan kinerja dan mengevaluasi prosedur (Davis \& Manrodt, 1997). Oleh karena itu, setiap perusahaan harus berupaya untuk meningkatkan layanan dan kepuasan pelanggan agar dapat bertahan dalam persaingan ini.

Studi untuk menganalisis antrean pada penelitian ini akan dilakukan di salah satu perusahaan yang bergerak di bidang logistik, yang menyediakan jasa pengiriman barang dan ekspedisi yang berlokasi di Cikarang, Bekasi dan berskala nasional. Tidak hanya pengiriman dengan skala besar, namun pengiriman secara perorangan atau skala kecil pun sangat diminati saat ini.

Saat ini, di counter sering terjadi penumpukan antrean orang yang ingin mengirimkan barang. Berdasarkan pengamatan, antrean ini sering terjadi khususnya pada jam-jam istirahat, sore hari, dan khususnya di Sabtu. Selain disebabkan oleh banyaknya pengguna jasa, antrean juga terjadi karena petugas sering mengerjakan pengemasan item yang akan dikirim. Akibatnya, petugas sering terlihat kewalahan dan lelah karena harus melayani pelanggan sekaligus mengemas barang yang akan dikirim. Hal tersebut menyebabkan tingginya waktu tunggu bagi pelanggan, sehingga pelanggan merasa tidak nyaman dan sering mengeluh karena harus menunggu lama.

Simulasi adalah suatu proses peniruan dari sesuatu yang nyata beserta keadaan sekelilingnya (Banks et al., 2004). Simulasi merupakan suatu alat yang terintegrasi dalam melakukan perencanaan dan menjalankan sistem logistik yang rumit. Dengan semakin tingginya permintaan dan biaya, maka perencanaan dalam sistem logistik yang rumit, simulasi diperlukan untuk melakukan perencanaan dengan lebih baik (Schmidt, 1988). Thiers dan McGinnis (2011) telah melakukan penelitian tentang pemodelan dan simulasi logistik pada rantai pasok global dalam penyelesaian masalah untuk konteks enterprise.

Pada penelitian ini, kajian penanganan logistik pengiriman barang di counter dilakukan dengan menggunakan pendekatan teori antrean dan simulasi sistem. Pemilihan pendekatan simulasi sistem dilakukan karena keunggulannya dalam mengevaluasi sistem dan juga dalam melakukan simulasi perbaikan dari sistem tersebut. Walaupun sistem yang diamati cukup sederhana, namun ketidakpastian dalam proses terbilang cukup tinggi, sehingga akan lebih baik jika dipelajari dengan pendekatan simulasi sistem dibandingkan pendekatan analitis. Melalui pendekatan simulasi sistem, akan diketahui bagaimana interaksi setiap entitas saat ini, dan pada akhirnya dapat memberikan suatu perbaikan yang dapat meningkatkan layanan dan kepuasan pelanggan (Arwindy et al., 2014). Selain itu, pada penelitian ini juga diberikan usulan perbaikan dan juga hasil simulasi kinerja sistem berdasarkan usulan perbaikan. Untuk memudahkan pembuatan simulasi terhadap perbaikan sistem, ditetapkan asumsiasumsi dalam hal waktu perbaikan proses, dengan mengacu pada proporsional waktu aktivitas dan juga dari hasil percobaan dan pengamatan singkat.

\section{Metodologi}

\section{Sistem}

Menurut Blanchard (1991), sistem adalah sekumpulan elemen yang bekerja sama untuk mencapai tujuan yang diharapkan. Obyek yang menjadi komponen dari sistem dapat berupa obyek terkecil dan bisa juga berupa sub-sistem atau sistem yang lebih kecil lagi. Contoh dari sistem adalah sistem lalu lintas, sistem ekonomi dan sistem manufaktur.

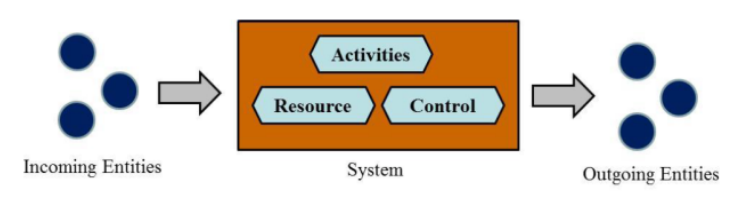

Gambar 1. Sistem dan elemennya

Harrel et al. (2000) menyatakan bahwa sistem terdiri dari beberapa elemen. Adapun elemen sistem tersebut adalah entities, 
activities, resources, dan control. Adapun hubungan elemen-elemen tersebut dalam suatu sistem dapat dilihat pada Gambar 1.

\section{Antrean}

Antrean merupakan suatu kejadian yang biasa dalam kehidupan sehari-hari. Di sektor manufaktur, sering kali terlihat antrean menuju beberapa part di suatu proses. Di sektor jasa, sering kali ditemukan antrean orang untuk mendapatkan pelayanan di restoran, bank, dan lain sebagainya. Antrean terjadi karena kebutuhan akan layanan melebihi kapasitas pelayanan atau fasilitas layanan, sehingga pengguna fasilitas yang tiba tidak bisa segera mendapat layanan.

Berdasarkan teori, antrean dapat digolongkan ke dalam empat jenis (Heizer \& Render, 2013), yaitu:

1. Sistem antrean satu jalur dengan satu server (Single Channel Single Phase). Hanya terdapat satu jalur antrean yang memasuki sistem pelayanan dan hanya dilayani oleh satu fasilitas penyedia jasa (server). Misalnya, seorang operator loket penjual tiket yang melayani antrean pelanggan yang ingin membeli tiket.

2. Sistem antrean multi jalur dengan satu server (Multi Channel Single Phase). Hanya terdapat satu jalur antrean, namun dilayani oleh lebih dari satu fasilitas penyedia jasa, sehingga menyebabkan antrean terbagi sesuai dengan jumlah fasilitas tersebut. Misalnya, sejumlah teller bank yang melayani sehingga setiap pelanggan yang menunggu akan dilayani oleh teller yang kosong atau idle.

3. Sistem antrean satu jalur dengan multi server (Single Channel-Multi Phase). Hanya ada satu jalur antrean dengan tahapan berganda atau lebih pelayanan yang dilakukan secara berurutan.

4. Sistem antrean multi jalur dengan multi fase (Multi Channel-Multi Phase). Antrean terdiri dari beberapa fase, jadi pelayanan terpecah ke dalam beberapa fasilitas penyedia jasa yang melakukan aktivitas yang berbeda - beda namun saling berhubungan.

\section{Pendekatan Simulasi}

Simulasi adalah suatu cara untuk menduplikasi/menggambarkan ciri, tampilan, dan karakteristik dari suatu sistem nyata.
Dengan melakukan studi simulasi maka dalam waktu singkat dapat ditentukan keputusan yang tepat serta dengan biaya yang tidak terlalu besar karena semuanya cukup dilakukan dengan komputer.

Pendekatan simulasi diawali dengan pembangunan model sistem nyata. Model tersebut harus dapat menunjukkan bagaimana berbagai komponen dalam sistem saling berinteraksi sehingga benar-benar menggambarkan perilaku sistem. Setelah model dibuat maka model tersebut ditransformasikan ke dalam program komputer sehingga memungkinkan untuk disimulasikan. Law \& Kelton (1991) menyatakan bahwa simulasi merupakan salah satu cara dalam melakukan eskperimen pada model untuk menganalisis sistem nyata. Hal ini dapat dilihat pada Gambar 2.

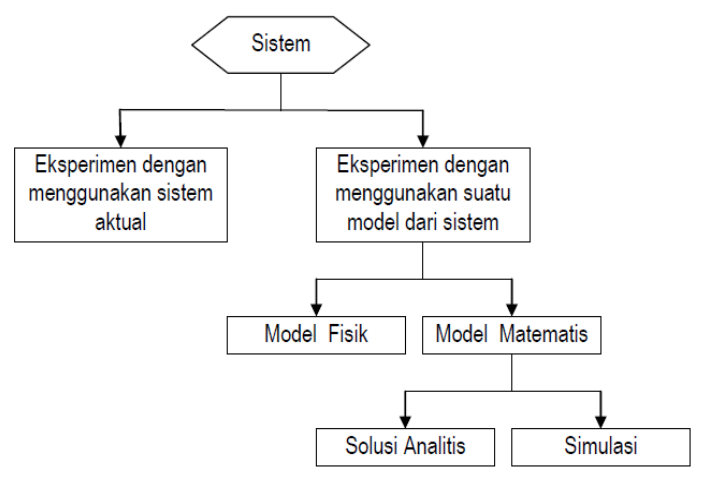

Gambar 2. Pendekatan dalam eksperimen

\section{Pembuatan Model Simulasi}

Proses pembuatan model simulasi dimulai dengan menerjemahkan sistem nyata ke dalam model konseptual, model konseptual kemudian diterjemahkan ke dalam model simulasi. Proses ini berlangsung secara berulang (iterative) dan rentan terjadi error, oleh sebab itu verifikasi dan validasi digunakan untuk mengurangi adanya eror tersebut.

Verifikasi merupakan proses menentukan apakah model simulasi telah mencerminkan model konseptual (Hoover \& Perry, 1989). Validasi merupakan proses penentuan apakah model simulasi, sebagai konseptualisasi atau abstraksi merupakan representasi berarti dan akurat dari sistem nyata (Hoover \& Perry, 1989).

\section{Langkah-langkah Penelitian}

Pengamatan dilakukan secara langsung di lokasi. Dari pengamatan diharapkan akan 
didapatkan data-data yang dibutuhkan untuk simulasi. Data yang dikumpulkan dengan metode wawancara maupun pengamatan langsung selanjutnya akan diolah. Pengolahan data ini untuk memastikan bahwa data telah cukup dan telah sesuai dengan kondisi sistem sesungguhnya.

Metode observasi dan wawancara digunakan untuk mendapatkan informasi, informasi terkait situasi di lokasi counter. Setelah itu akan dibangun model sistem yang merepresentasikan kondisi nyata sistem tersebut. Setelah model sistem terbentuk, dilakukan pembangunan model layout di software Promodel.

Langkah selanjutnya adalah proses pengecekan verifikasi dan validasi terhadap model-model yang telah dibangun sebelumnya. Verifikasi digunakan untuk mengecek apakah model yang dibangun telah sesuai dengan model sistem nyata. Validasi digunakan untuk mengecek apakah model yang dibangun telah sesuai atau merepresentasikan sistem nyata. Langkah selanjutnya adalah dilakukan perbaikan model simulasi untuk proses optimalisasi pada kondisi sistem nyata dengan aktivitas perbaikan. Output dari simulasi kondisi awal dan model simulasi yang telah diperbaiki tersebut kemudian dianalisis untuk melihat hasil perbaikan yang telah dilakukan. Adapun keseluruhan langkah penelitian dapat dilihat pada Gambar 3.

\section{Hasil dan Diskusi}

\section{Model Simulasi Sistem Saat Ini}

Model sistem dibuat dengan tujuan untuk menyimulasikan kondisi antrean yang ada, melakukan eksperimen pada model untuk mengatasi permasalahan yang ada. Model simulasi dibuat menggunakan software Promodel versi 7,5 . Sebelum membuat model simulasi terhadap sistem saat ini, perlu dilakukan pengambilan data setiap kegiatan dan melakukan uji pendahuluan terhadap data. Pengujian data juga dilakukan dengan software Promodel, yaitu dengan fitur Statfit. Adapun uji pendahuluan yang dilakukan mencakup uji independensi dan uji autokorelasi. Setelah itu juga dilakukan pengujian dan penentuan distribusi peluang dari setiap aktivitas. Setelah uji pendahuluan selesai, maka dilanjutkan dengan membangun model sebagaimana yang ditunjukkan pada Gambar 4.

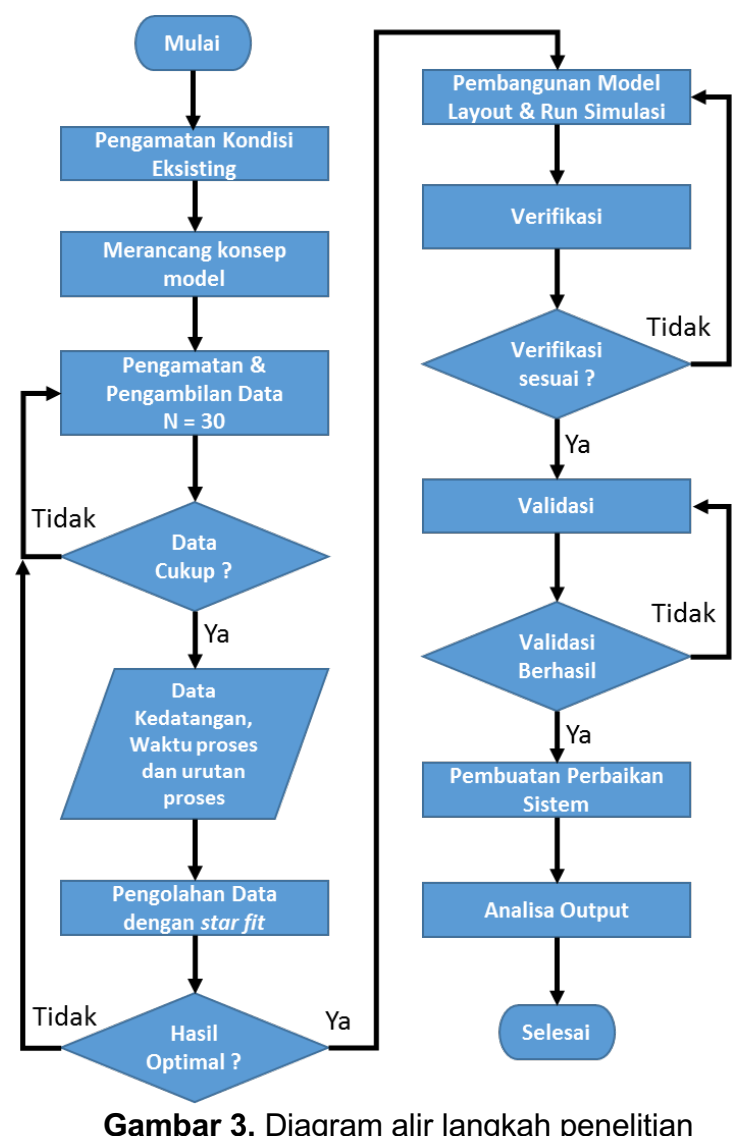

Gambar 3. Diagram alir langkah penelitian

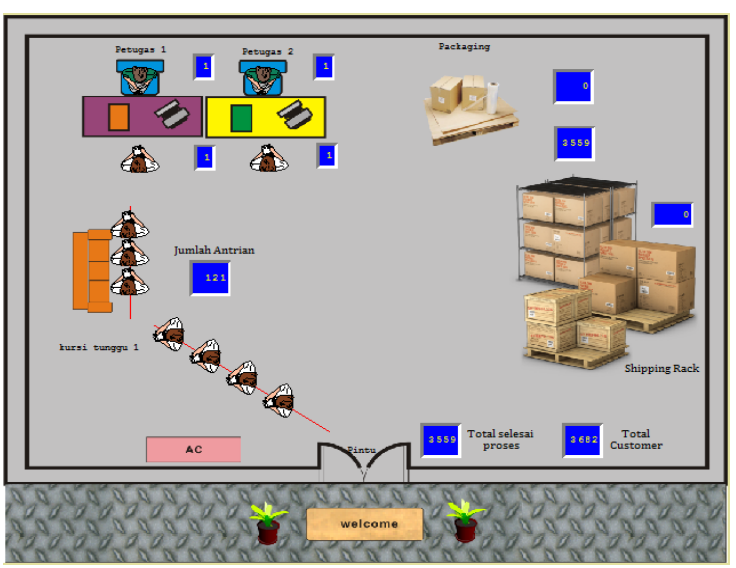

Gambar 4. Model sistem kondisi awal

Pada Gambar 4 dapat dilihat bahwa begitu pelanggan memasuki counter, maka pelanggan harus mengantre di ruang tunggu. Terdapat dua karyawan yang melayani pelanggan, dan jika salah satu karyawan sudah kosong, maka pelanggan akan langsung dilayani secara bergantian. Setelah pelanggan bertemu dengan salah satu karyawan, maka dimulai proses pengiriman, di mana proses ini memakan waktu yang lama dan bervariasi, karena ada beberapa proses, 
meliputi pendaftaran, pencatatan, pengembalian uang, dan juga proses pengepakan barang. Setelah selesai, maka pelanggan dapat keluar counter dan paket yang telah dikemas, langsung dipindahkan ke rak barang siap kirim.

Setelah menjalankan model simulasi dengan replikasi 30 kali, maka dilakukan verifikasi dan validasi sistem. Verifikasi dilakukan dengan menggunakan tracing di Promodel dan dicek apakah sudah sesuai dengan proses layanan sesuai dengan sistem nyata atau tidak. Selain itu, dilakukan juga face validity yaitu dengan melakukan konfirmasi hasil simulasi dengan pihak manajemen. Setelah dinyatakan sesuai, maka dilakukan validasi dengan melakukan $t$-test dua sampel, yang membandingkan output model simulasi, yaitu total pelanggan yang sudah dilayani, selama 8 jam dengan 30 replikasi, dengan jumlah pelanggan aktual yang dilayani counter setiap hari (8 jam) selama 30 hari, berdasarkan data catatan perusahaan. Dari hasil pengujian t-test 2 sampel dengan menggunakan Minitab didapatkan nilai $P$-value $>0,05$ yaitu 0,111 sehingga dapat disimpulkan bahwa tidak ada perbedaan yang berarti secara statistik dari hasil model simulasi dengan output aktual sistem nyata.

\section{Identifikasi Penyebab Masalah}

Sebelum membuat usulan perbaikan sistem, maka terlebih dahulu dilakukan identifikasi penyebab masalah. Identifikasi dilakukan dengan pengamatan langsung terhadap sistem selama beberapa hari. Hasil pengamatan kemudian di klarifikasi kepada karyawan untuk mengkonfirmasi masalah yang terjadi di sistem. Beberapa aktivitas yang menyebabkan lamanya penanganan terhadap pelanggan adalah sebagai berikut:

1. Pengisian alamat dan identitas

Customer yang belum teregister membuat customer harus melakukan pengisian identitas terlebih dahulu, kemudian diinput di dalam sistem komputer oleh petugas. Hal ini menjadi salah satu faktor dominan penyebab antrean menjadi banyak.

2. Negosiasi harga pengiriman barang

Negosiasi terkadang dilakukan oleh customer agar mendapatkan harga yang lebih murah. Aktivitas negosiasi ini menjadi salah satu penyebab terjadinya antrean banyak.
3. Uang kembalian

Customer sering kali melakukan pembayaran dengan uang yang tidak pas. Ketika uang kembalian yang tersedia ternyata kurang jumlah pada saat pengembalian, maka petugas harus mencari dahulu agar uang pengembalian cukup untuk customer.

\section{Usulan Perbaikan Sistem}

Setelah mengidentifikasi penyebab masalah, maka dikembangkan suatu usulan perbaikan. Hasil diskusi dengan manajemen mengharapkan adanya usulan perbaikan yang dapat dilakukan dalam waktu cepat dan juga dalam waktu yang lama. Terdapat dua usulan perbaikan, yaitu perbaikan jangka pendek dan perbaikan jangka panjang. Perbaikan jangka pendek hanya ditujukan untuk perbaikan proses pelayanan oleh petugas terhadap customer dan belum mencakup perbaikan di daerah pembungkusan. Perbaikan jangka panjang digunakan untuk memperbaiki proses antrean dan mempercepat proses pengemasan barang.

Usulan perbaikan jangka pendek yang dilakukan adalah sebagai berikut:

1. Penyediaan form identitas khusus untuk customer yang belum register, sehingga penulisan identitas tidak dilakukan pada saat proses pelayanan oleh petugas. Proses pengisian form ini dirancang sederhana dan jelas sehingga siapapun customer yang mengisi form, tidak akan menemui kesulitan.

2. Penyediaan dan persiapan uang pecahan kecil untuk membantu mengurangi faktor lamanya mencari dan penukaran uang pada saat proses pelayanan berlangsung.

Dari perbaikan tersebut, peneliti mengasumsikan bahwa perbaikan yang dicapai dapat mempercepat waktu pelayanan menjadi antara 3 sampai dengan 5 menit dari sebelumnya 3 sampai dengan 7 menit. Asumsi dibuat berdasarkan hasil percobaan singkat dan juga diskusi dengan karyawan yang melayani di counter. Setelah melakukan simulasi terhadap perbaikan jangka pendek, didapatkan perubahan rata-rata untuk customer waiting time yaitu dari 90,87 menit menjadi 42,41 menit atau mengalami penurunan sebesar 48,46 menit $(53,32 \%)$.

Sedangkan pada uji paired t-test didapatkan nilai $P$-value $<0,05$ yaitu 0,00 , 
sehingga dapat disimpulkan bahwa perbaikan jangka pendek yang telah dibuat dalam model simulasi memiliki perbedaan dari sisi customer waiting time kondisi layanan saat ini.

Usulan perbaikan jangka panjang yang dilakukan adalah sebagai berikut:

1. Pemakaian sistem informasi secara online untuk melakukan pendataan customer, alamat tujuan pengiriman dan harga dari pengiriman. Dengan ini customer hanya datang ke counter untuk melakukan pembayaran dengan uang pas dan mengantarkan barang untuk dikirim, atau hanya mengantar barang saja karena pembayaran sudah dilakukan dengan melalui fasilitas transfer/internet banking.

2. Standardisasi proses dan harga untuk barang-barang yang akan dikirim dengan menggunakan asuransi. Sehingga mengurangi proses negosiasi dan pengecekan barang.

3. Dalam sistem hanya ada seorang petugas kasir yang akan melayani customer.

4. Satu orang petugas lainnya dijadikan khusus untuk kegiatan pengemasan barang. Sehingga barang dapat terkemas tepat waktu sebelum dikirim.

Dari perbaikan tersebut peneliti mengasumsikan bahwa perbaikan yang dicapai dapat mempercepat waktu pelayanan menjadi antara 1 sampai dengan 3 menit, dari semula 3 sampai dengan 7 menit. Selain itu, proses pengemasan dipercepat dengan menjadikan satu orang khusus yang bertugas untuk mengemas barang. Perbaikan pada proses pengemasan yang lebih efisien dapat meningkatkan kinerja pelayanan seperti memperpendek waktu tunggu, meningkatkan jumlah produk yang berhasil dikemas, dan mempersingkat lead time (Dominic, 2010).

Adapun tampilan model simulasi usulan perbaikan jangka panjang, dapat dilihat pada Gambar 5.

Setelah melakukan simulasi terhadap perbaikan jangka panjang, didapatkan perubahan rata-rata untuk waktu tunggu pelanggan yaitu dari 90,87 menit menjadi 28,53 menit. Jadi waktu tunggu pelanggan lebih cepat atau mengalami penurunan sebesar 62,34 menit atau $68,6 \%$. Selain itu pada bagian pengemasan meningkat menjadi 268,23 unit per hari (lebih banyak unit yang terkemas) oleh karena ada tambahan petugas khusus pengemasan. Uji paired t-test didapatkan nilai $P$-value $<0,05$ yaitu 0,00 sehingga dapat disimpulkan bahwa hasil perbaikan jangka panjang yang telah dibuat dalam model simulasi memiliki perbedaan dari dibandingkan hasil kondisi layanan saat ini.

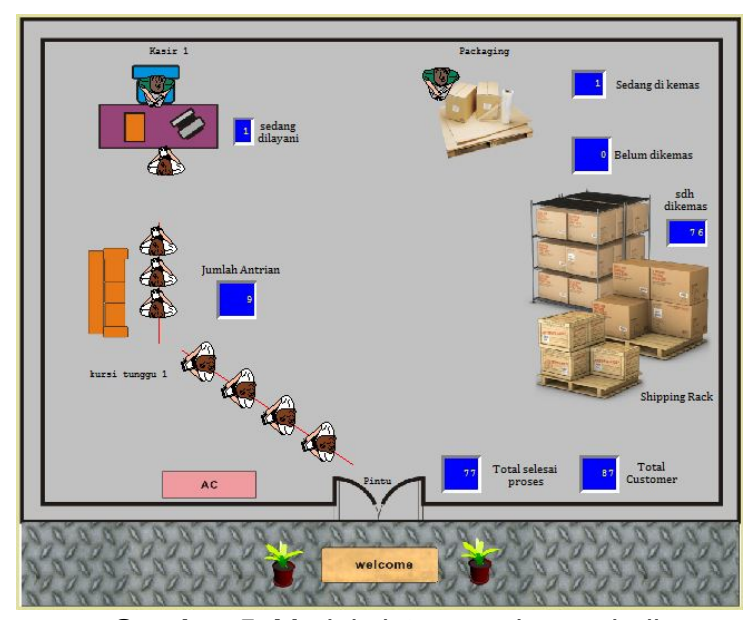

Gambar 5. Model sistem usulan perbaikan jangka panjang

Secara singkat, perbandingan antara sistem saat ini dan usulan sistem perbaikan untuk jangka Panjang dapat dilihat pada Tabel 1.

Tabel 1. Perbandingan sistem saat Ini dan usulan

\begin{tabular}{|l|c|c|}
\hline & Saat ini & Usulan \\
\hline $\begin{array}{l}\text { Rata-rata waktu } \\
\text { tunggu pelanggan } \\
\text { (menit) }\end{array}$ & 90,87 & 28,53 \\
\hline $\begin{array}{l}\text { Jumlah unit yg } \\
\text { dikemas/hari }\end{array}$ & $3-7$ & 268,23 \\
\hline $\begin{array}{l}\text { Proses pelayanan } \\
\text { per pelanggan } \\
\text { (menit) }\end{array}$ & serabutan & $\begin{array}{c}\text { Satu } \\
\text { operator } \\
\text { khusus } \\
\text { pengemasan }\end{array}$ \\
\hline Operator & &
\end{tabular}

\section{Kesimpulan}

Penelitian ini dilakukan untuk menganalisis sistem layanan pada salah satu perusahaan jasa pengiriman barang dan ekspedisi di Cikarang. Adapun beberapa kesimpulan yang dapat diberikan pada penelitian ini adalah:

1. Dengan menggunakan simulasi, dapat diketahui kondisi dari suatu proses atau sistem. Hasil simulasi menunjukkan secara eksplisit kinerja dari sistem dan juga dapat dijadikan dasar dalam menentukan prioritas dalam perbaikan sistem. Pendekatan simulasi juga memungkinkan untuk melakukan uji coba usulan perbaikan sistem, sehingga sebelum diterapkan, 
dapat diketahui terlebih dahulu kemungkinan kinerjanya.

2. Usulan perbaikan yang dapat diterapkan dan dilakukan di perusahaan logistik ini adalah perbaikan di area proses pelayanan customer dan area pengemasan.

3. Dari hasil analisis didapatkan beberapa alternatif perbaikan yaitu jangka pendek dan jangka panjang yang dapat mengurangi waktu tunggu pelanggan dan meningkatkan jumlah barang yang dikemas. Perbaikan jangka pendek antara lain dengan menyediakan form isian identitas dan penyediaan uang untuk pengembalian. Hal ini dapat membantu untuk mempercepat proses pelayanan customer, sehingga antrean menjadi lebih sedikit. Perbaikan jangka panjang yaitu menerapkan sistem registrasi dan pelayanan online sehingga customer datang ke counter hanya untuk membayar dan mengantar barang yang akan dikirim, ataupun hanya mengantar barang saja apabila pembayaran dilakukan secara transfer rekening Bank. Oleh karena itu, antrean akan menjadi pendek dan proses pelayanan customer di counter menjadi lebih cepat.

Penelitian ini memberikan dukungan mengenai pentingnya pendekatan simulasi dalam mengetahui kinerja sistem, termasuk juga dalam hal sistem layanan pengiriman barang dan ekspedisi. Berdasarkan hasil simulasi, didapatkan bahwa kedua usulan perbaikan sistem akan memberikan peningkatan produktivitas dari sistem. Penelitian ini memiliki keterbatasan sehingga dapat dilakukan kajian tambahan. Penelitian ini tidak mempertimbangkan biaya yang diperlukan dalam melakukan perbaikan. Pihak manajemen diharapkan untuk melakukan evaluasi lanjutan khususnya dalam hal analisis benefit-cost dari setiap usulan perbaikan.

\section{Daftar Pustaka}

Arwindy, F., Buulolo, F., \& Rosmaini, E. (2014). Analisis dan Simulasi Sistem Antrean pada Bank ABC. Saintia Matematika, 2(2), 147-162.

Banks, J., Carson II, J.S., Nelson, B.L., \& Nicol, D.M. (2004). Discrete-Event System Simulation (4th ed.). Prentice Hall.

Blanchard, B.S. (1991). System Engineering Management. New York: John Wiley \& Sons.

Davis, F. W., \& Manrodt, K. B. (1997). Logistics: An Introduction. International Journal of Physical Distribution \&Logistics Management, 21(7), 4-13.

Dominic, C. (2010). Packaging Logistics Performance. Thesis for the Degree of Doctor of Philosophy. Department of Design Sciences Division of Packaging Logistics Lund University.

Harrell, C., Ghosh, B. K., \& Bowden, R. (2000). Simulation Using Promodel. United States of America: McGraw-Hill Companies, Inc.

Heizer, J., \& Render, B., (2013).Operations Management: Sustainability and Supply Chain Management, (11 $11^{\text {th }}$ ed). Pearson Education.

Hoover, S.V., \& Perry, R. F. (1989). Simulation A Problem-Solving Approach. Digital Equipment Corporation \& Northeastern University.

Law, A. M., \& Kelton, W. D. (1991). Simulation Modeling \& Analysis, (2nd ed.). New York: McGraw-Hill; International.

Schmidt, A. K. R. (1988). Simulation of Logistic System. Logistics World, 1(1), 47-52.

Thiers, G., \& McGinnis, L. (2011). Logistics Systems Modeling and Simulation. Proceedings - Winter Simulation Conference, 1531-1541. 
Halaman ini sengaja dikosongkan.

This page is intentionally left blank. 